Vol 1. No 2. November 2021, e-ISSN : 2807-1670 | p-ISSN : 2807-2316

\title{
UPAYA PENINGKATAN KEAKTIFAN DAN HASIL BELAJAR SISWA MELALUI PENERAPAN METODE ROLE PLAYING PADA MATA PELAJARAN BAHASA INGGRIS DI MAN 5 SLEMAN
}

\author{
NOOR HAYANTI \\ MAN 5 Sleman Yogyakarta \\ Email : noorhayanti.effendi@gmail.com
}

\begin{abstract}
ABSTRAK
Penelitian ini dilaksanakan untuk meningkatkan keaktifan dan hasil belajar siswa dengan menggunakan metode role playing di MAN 5 Sleman. Peningkatan keaktifan belajar dan hasil belajar siswa dilakukan dengan menggunakan metode role playing. Penelitian ini merupakan penelitian tindakan kelas yang dilaksanakan dalam dua siklus. Setiap siklus terdiri dari perencanaan, tindakan, observasi, dan refleksi. Subyek penelitian ini adalah siswa kelas XII IPA yang berjumlah 29 siswa. Teknik pengumpulan data yang digunakan dalam penelitian ini yaitu observasi dan tes tertulis. Observasi digunakan untuk mengetahui keaktifan belajar siswa, sedangkan tes digunakan untuk mengetahui hasil belajar. Hasil penelitian menunjukkan bahwa dengan penerapan metode role playing, keaktifan belajar siswa dari kondisi awal, siklus 1, dan siklus 2 meningkat. Hal ini terlihat dari persentase aktivitas pada kategori rendah yang terus menurun dari 62,1\% - 50,0\% - 8,6\%, kategori sedang meningkat dari 34,5\% - 43,1\% - 53,4\% dan kategori tinggi meningkat dari 3,4\% - 6,9\% - 38\%. Peningkatan juga terjadi pada skor hasil belajar siswa. Dari kondisi awal, siklus 1 ke siklus 2 mengalami peningkatan. Siswa yang tuntas pada kondisi awal sebesar 20,7\% meningkat menjadi $62,1 \%$ pada siklus 1 dan pada siklus 2 meningkat lagi menjadi 82,8\%. Hasil penelitian ini menunjukkan bahwa penerapan metode role playing telah berhasil karena adanya peningkatan aktivitas belajar dan hasil belajar siswa.

Kata kunci: Role playing, Hasil Belajar, Keaktifan Belajar Siswa
\end{abstract}

\section{ABSTRACT}

This research is conducted to improve the student learning activity and learning outcomes by using role playing method at MAN 5 Sleman. The improvement of the student learning activity and learning outcomes has been done by using role playing method. This research is classroom action research which was conducted in two cycles. Each cycle consisting of planning, action, observation, and reflection. The subject of this research is the twelve science graders with the total number of students are 29. The data collection techniques used in this study were observation and written test. Observation is used to determine the activeness of students, while test is used to determine learning outcomes. The results showed that by the implementation of the role playing method, the activeness of students from the former condition, cycle 1, and cycle 2 increased. This can be seen from the percentage of activity in the low category that continues to decline from $62,1 \%-50,0 \%-8,6 \%$, the medium category increased from $34,5 \%-43,1 \%$ $53,4 \%$ and the high category increased from 3,4\% - 6,9\% - 38\%. An increase also occurred in the score of student learning outcomes. From the former conditioncycle 1 to cycle 2 has increased. Students who completed in the former condition were $20,7 \%$ increased to $62,1 \%$ in cycle 1 and in cycle 2 increased to 82,8\%. The results of this study showed that the implementation of role playing strategy has been successful since there was an increase in students learning activity and learning outcomes.

Key words: Role Playing, Learning Outcomes, Students Learning Activity

\section{PENDAHULUAN}

Bahasa Inggris merupakan alat untuk berkomunikasi secara lisan dan tulisan. Pengertian berkomunikasi dimaksudkan adalah memahami dan mengungkapkan informasi, pikiran, perasaan serta mengembangkan ilmu pengetahuan, teknologi, dan budaya dengan menggunakan bahasa Inggris. 
Kemampuan komunikasi dalam pengertian yang utuh adalah kemampuan berwacana. Adapun fungsi dan tujuan pengajaran bahasa Inggris, dalam konteks pendidikan, bahasa Inggris berfungsi sebagai alat untuk berkomunikasi dalam rangka mengakses informasi, dan dalam konteks sehari-hari, sebagai alat untuk membina hubungan interpersonal, dan bertukar informasi. Mata pelajaran bahasa Inggris memiliki tujuan sebagai berikut : Mengembangkan kemampuan berkomunikasi dalam bahasa Inggris, dalam bentuk lisan dan tulis.

Kemampuan berkomunikasi meliputi mendengarkan (listening), berbicara (speaking), membaca (reading) dan menulis (writing). Menumbuhkan kesadaran tentang hakikat dan pentingnya bahasa Inggris sebagai salah satu bahasa asing untuk menjadi alat utama belajar. Mengembangkan pemahaman tentang saling keterkaitan antar bahasa dan budaya serta memperluas cakrawala budaya. Oleh karena itu, mata pelajaran bahasa Inggris diarahkan untuk mengembangkan keterampilan-keterampilan tersebut agar lulusan mampu berkomunikasi dan berwacana dalam bahasa Inggris pada tingkat literasi tertentu.

Di dalam dunia pendidikan, bahasa Inggris menjadi salah satu mata pelajaran yang harus dikuasai mulai dari SMP/MTs, SMA/MAN sampai dengan tingkat perguruan tinggi. Hal ini dimaksudkan agar peserta didik mampu menguasai bahasa internasional tersebut sehingga dapat meningkatkan sumber daya manusia dan bisa bersaing di kancah internasional.

Mata pelajaran bahasa Inggris di MAN 5 Sleman masih dianggap sebagai mata pelajaran yang sulit dipahami dan kurang menarik. Hal ini disebabkan oleh beberapa faktor, diantaranya: (1) Metode pembelajaran yang digunakan oleh guru kurang menarik, (2) Siswa hanya dibekali dengan materi yang dipersiapkan untuk menjawab soal-soal ujian saja, (3) Kurangnya praktik-praktik berbahasa seperti berbicara, mendengar, menulis, dan membaca, (4) Kegiatan belajar monoton dan kurang bervariasi. Hal tersebut berdampak pada hasil belajar dan kurangnya keaktifan peserta didik dalam pembelajaran.

Dibandingkan dengan pembelajaran tatap muka, belajar secara daring membuat siswa menjadi kurang aktif terlibat dalam kegiatan belajar. Tingkat pemahaman yang kurang dari pembelajaran tanpa tatap muka mengakibatkan hasil belajar juga rendah. Hal ini bisa dilihat pada hasil belajar peserta didik berdasarkan hasil analisis nilai ulangan harian, sebagai berikut : peserta didik yang memperoleh nilai di bawah KKM sebesar 79,3\%, peserta didik yang sudah mencapai nilai KKM hanya 20,7\%.

Hasil yang diharapkan seharusnya $80 \%$ peserta didik sudah mencapai KKM bahkan melebihi dan maksimal hanya $20 \%$ yang nilainya di bawah KKM. Jika hasil belajar mata pelajaran bahasa Inggris tidak mencapai nilai yang memuaskan, maka akan berdampak pada rendahnya kemampuan berkomunikasi dalam bahasa Inggris peserta didik. Sehingga akan menghambat dalam proses transfer ilmu pengetahuan yang dalam masa modern ini dan masa yang akan datang lebih banyak menggunakan bahasa Inggris sebagai bahasa tingkat dunia.

Hasil belajar adalah perubahan tingkah laku secara keseluruhan bukan hanya salah satu aspek potensi kemanusiaan saja (Thobroni: 2012). Dipertegas oleh Nawawi dalam K. Brahim, hasil belajar diartikan sebagai tingkat keberhasilan siswa dalam mempelajari materi pelajaran di sekolah yang dinyatakan dalam skor yang diperoleh dari hasil tes mengenai materi pelajaran tertentu (Susanto:2016).

Menurut Hamalik (2001) bukti bahwa seseorang telah belajar (hasil belajar) terjadinya perubahan tingkah laku pada orang tersebut, misalnya dari tidak tahu menjadi tahu, dan dari tidak mengerti menjadi mengerti.

Demikian pula keaktifan peserta didik juga terlihat rendah berdasarkan hasil pengamatan. Pada kondisi awal tingkat keaktifan peserta didik adalah sebagai berikut: kategori tinggi 3,4\%, sedang $34,4 \%$, dan yang rendah mencapai $62,0 \%$.

Dari analisis penyebab masalah di atas maka dipandang perlu untuk meningkatkan keaktifan dan hasil belajar melalui model pembelajaran yang cocok dan tepat serta memungkinkan untuk dilakukan lewat daring, yakni melalui penerapan metode role playing.

Bermain peran atau role playing adalah metode pembelajaran dimana siswa memerankan suatu peran dari tokoh-tokoh dengan tujuan mendramatisasikan dan 
mengekspresikan gerak-gerik, tingkah laku seseorang seperti yang ada dalam kehidupan nyata. Metode bermain peran ini menekankan pada keterlibatan emosional pada masalah yang sedang dihadapi dalam kehidupan nyata. Siswa secara aktif bertanya dan menjawab dengan teman atau kelompoknya pada situasi tertentu yang diberikan oleh guru sesuai dengan materi yang sedang diajarkan.

Pratiwi (Agus, 2016) mengatakan role playing adalah bermain peran, yang berpusat pada peserta didik. Role playing menekankan sifat sosial pembelajaran, dan melihat perilaku kerjasama siswa untuk merangsang baik secara sosial maupun intelektual. Role playing sebagai strategi pengajaran menawarkan beberapa keuntungan untuk guru dan siswa.

Metode role playing mendorong peserta didik berkomunikasi dengan teman, merespon dan produktif. Model ini juga menumbuhkan sikap menghargai pendapat teman, mengeluarkan pendapat dan berinteraksi secara efektif dalam kelompoknya dan lingkungannya.

Berdasarkan uraian di atas maka tujuan dari penelitian tindakan kelas ini adalah untuk mengetahui peningkatan keaktifan dan hasil belajar peserta didik MAN 5 Sleman kelas XII MIPA melalui penerapan metode role playing.

\section{METODE PENELITIAN}

Penelitian ini adalah Penelitian Tindakan Kelas (Classroom Action Research). PTK ini dilaksanakan dengan bersiklus dan setiap siklusnya terdiri dari empat komponen, yaitu komponen perencanaan (planning), tindakan (acting), pengamatan (observing) dan refleksi (reflecting).

Penelitian tindakan kelas ini dilakukan dalam dua siklus. Setiap siklus terdiri dari dua pertemuan, sehingga secara keseluruhan ada empat pertemuan yang berlangsung selama dua bulan. Hasil yang diharapkan dari setiap siklus adalah adanya perubahan tingkah laku peserta didik dan hasil belajar yang meningkat. Secara skematis, prosedur penelitian ini bisa dilihat dari gambar berikut ini:

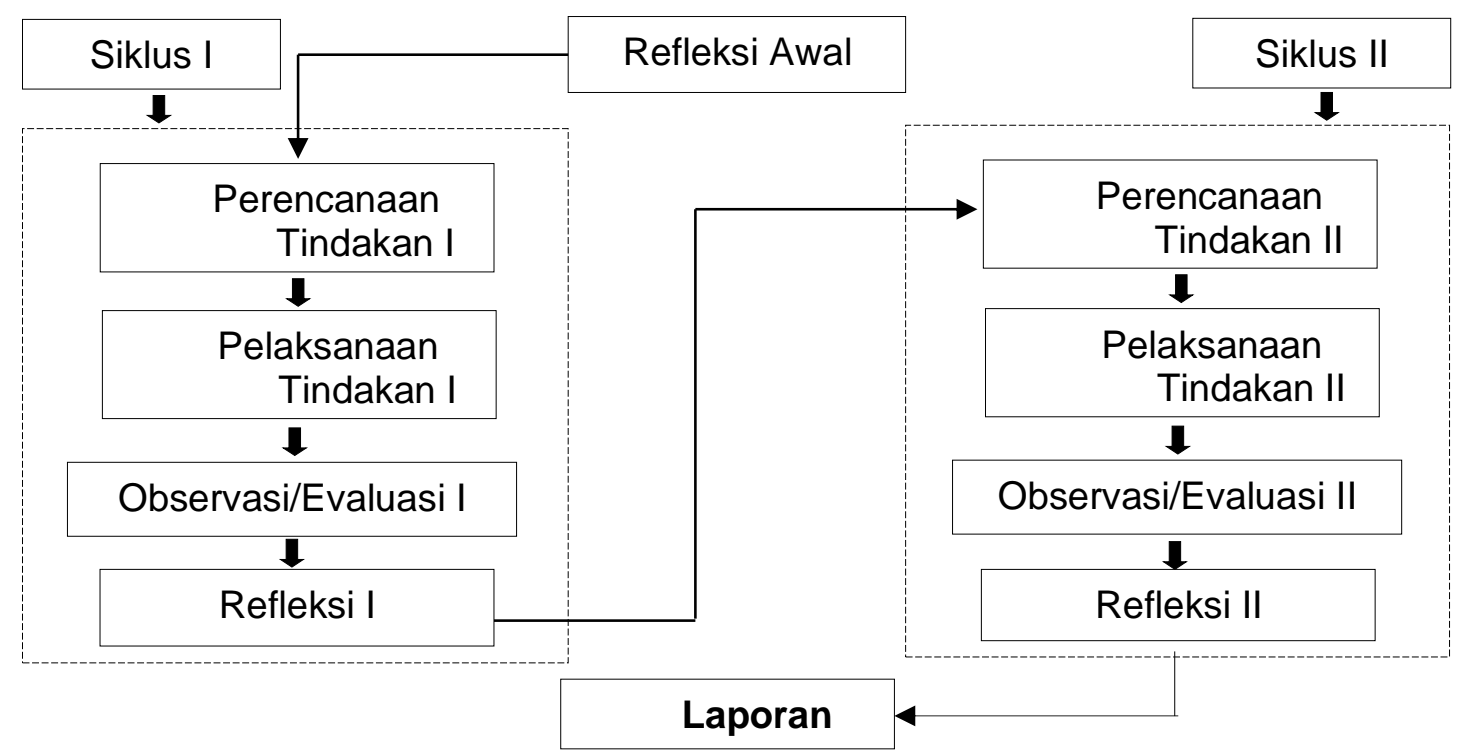

Gambar 1. Rancangan penelitian tindakan kelas

\section{HASIL PENELITIAN DAN PEMBAHASAN}

\section{A. Deskripsi Kondisi Awal}

Dari hasil pengamatan awal dari penelitian yang dilaksanakan di kelas XII MIPA 1 Madrasah Aliyah Negeri 5 Sleman, diketahui bahwa keaktifan mereka dalam pembelajaran bahasa Inggris rata-rata rendah. Berdasarkan observasi diketahui bahwa siswa yang keaktifannya rendah mencapai $62,1 \%$, sedang $34,5 \%$ dan tinggi $3,4 \%$. Demikian juga hasil belajar mereka pada mapel bahasa Inggris, dilihat dari nilai penilaian harian setelah menyelesaikan satu KD dalam satu bulan, sangat rendah. Peserta didik yang memperoleh 
nilai di bawah KKM sebesar 79,3\%, sementara peserta didik yang mempunyai nilai sudah mencapai KKM hanya 20,7\%. Kondisi awal keaktifan dan hasil belajar peserta didik dapat ditunjukkan dari tabel di bawah ini:

Tabel 1. Keaktifan Siswa pada Kondisi Awal

\begin{tabular}{|c|l|c|c|c|}
\hline No & Kategori Keaktifan & Kondisi awal & Siklus 1 & Siklus 2 \\
\hline 1 & Tinggi & $3,4 \%$ & & \\
\hline 2 & Sedang & $34,5 \%$ & & \\
\hline 3 & Rendah & $62,1 \%$ & & \\
\hline
\end{tabular}

Tabel 2. Hasil Belajar Siswa pada Kondisi Awal

\begin{tabular}{|c|l|c|c|c|}
\hline No & \multicolumn{1}{|c|}{ Kategori Nilai } & Kondisi awal & Siklus 1 & Siklus 2 \\
\hline 1 & $\begin{array}{l}\text { Belum Tuntas } \\
(<\mathrm{KKM})\end{array}$ & $79,3 \%$ & & \\
\hline 2 & Tuntas $(=/>\mathrm{KKM})$ & $20,7 \%$ & & \\
\hline
\end{tabular}

\section{B. Deskripsi Hasil Penelitian}

1. Siklus 1

a. Perencanaan tindakan siklus 1

Rencana tindakan pada siklus 1 bertujuan untuk memperbaiki keaktifan dan hasil belajar siswa. Yang pertama dibuat Rencana Pelaksanaan Pembelajaran (RPP) untuk dua kali pertemuan (RPP terlampir). RPP dikembangkan dengan menggunakan metode role playing yang merupakan salah satu bentuk model pembelajaran cooperative learning sesuai dengan langkah-langkah yang dibahas dalam kajian teori. Kompetensi yang akan diajarkan dalam RPP ini adalah KD 3.1. RPP ini akan diimplementasikan pada pertemuan pertama dan kedua, yakni tanggal 18 September 2020 dan 26 September 2020.

Adapun langkah-langkah pembelajaran yang direncanakan (secara detail tertuang dalam RPP) adalah sebagai berikut :

1) Menetapkan materi pembelajaran

2) Mereview ulang pembelajaran sebelumnya

3) Menetapkan tujuan pembelajaran

4) Menetapkan langkah-langkah pembelajaran

5) Menjelaskan konsep baru

6) Membuat kelompok kerja

7) Memberi tugas siswa menyusun teks secara berkelompok

8) Mempresentasikan hasil diskusi kelompok

9) Siswa yang lain mengamati dan memberi komen terhadap penampilan kelompok lain

10) Guru memberikan feedback atas penampilan siswa

11) Guru memberikan tugas mandiri untuk mengetahui tingkat penguasaan materi

b. Pelaksanaan Tindakan Siklus 1

Berdasarkan hasil observasi yang dilakukan oleh dua observer (teman sejawat), dengan menggunakan lembar observasi (terlampir) dalam dua kali pertemuan, yakni pertemuan pertama hari Jum'at tanggal 18 September 2020 dan pertemuan ke dua hari Sabtu tanggal 26 September 2020, ditemukan bahwa proses pembelajaran berlangsung sebagai berikut:

1) Pertemuan pertama

Proses pembelajaran secara umum sudah baik dan sesuai dengan langkahlangkah metode role playing. Namun ada beberapa langkah pembelajaran yang tidak dilakukan secara optimal, yaitu sebagai berikut: 
a) Memberi kesempatan siswa untuk membahas penampilan siswa yang lain masih kurang.

b) Beberapa siswa masih kurang aktif dan takut menyampaikan pendapat.

c) Optimalisasi dalam mendiskusikan hasil kerja kelompok harus dilakukan

2) Pertemuan ke dua

Proses pembelajaran secara umum sudah baik dan sesuai dengan langkahlangkah metode role playing. Namun ada beberapa langkah pembelajaran yang tidak dilakukan secara optimal, namun sudah lebih baik dari pertemuan pertama, yaitu sebagai berikut:

a) Pemberian waktu untuk membahas penampilan siswa yang lain sudah lebih baik dari pertemuan pertama.

b) Siswa sudah banyak yang berani menyampaikan pendapat meskipun lewat chat google meet.

c) Mendiskusikan hasil kerja kelompok sudah ada peningkatan, namun masih kurang dalam pengelolaan waktu.

c. Hasil Penelitian dan Refleksi Siklus 1

1) Hasil Penelitian Siklus 1

a) Hasil Keaktifan

Menurut observer 1 didapatkan data bahwa, persentase siswa yang memiliki keaktifan rendah ada 48,3 \%, sedang 44,8 \%, dan tinggi 6,9\%. Menurut observer 2 didapatkan data bahwa, persentase siswa yang memiliki keaktifan rendah ada $51,7 \%$, sedang $41,4 \%$, dan tinggi 6,9\%.

Jika di rata-rata dari dua observer tersebut diperoleh data bahwa persentase siswa yang keaktifannya rendah ada 50,0\%, sedang 43,1 \% dan tinggi 6,9\%. Kalau dibandingkan dengan kondisi awal adalah sebagai berikut:

Tabel 3. Keaktifan Siswa Kondisi Awal dan Siklus 1

\begin{tabular}{|c|l|c|c|c|}
\hline No & $\begin{array}{c}\text { Kategori } \\
\text { Keaktifan }\end{array}$ & Kondisi awal & Siklus 1 & Siklus 2 \\
\hline 1 & Tinggi & $3,4 \%$ & $6,9 \%$ & \\
\hline 2 & Sedang & $34,4 \%$ & $43,1 \%$ & \\
\hline 3 & Rendah & $62,0 \%$ & $50,0 \%$ & \\
\hline
\end{tabular}

Tabel di atas menunjukkan bahwa keaktifan siswa pada siklus 1 mengalami peningkatan pada kategori rendah dan sedang. Sedangkan pada kategori tinggi masih tetap. Namun pmenelitian belum dikatakan berhasil, karena indikator yang ditetapkan adalah jika persentase siswa yang keaktifannya dengan kategori rendah berada di bawah $10 \%$.

b) Hasil Belajar

Berdasarkan hasil tes yang dilakukan di akhir siklus 1 diketahui bahwa ratarata nilai yang diperoleh peserta dididk untuk mapel bahasa Inggris KD 3.1 (KKM 76) adalah 70,8 . Dengan kategori belum tuntas dan tidak tuntas sebagai berikut :

- Persentase belum tuntas : $11 / 29 \times 100 \%=37,9 \%$

- Persentase sudah tuntas : $18 / 29 \times 100 \%=62,1 \%$

Bila dibandingkan dengan hasil belajar pada kondisi awal, hasil belajar pada siklus ini mengalami peningkatan. Hal ini dapat dilihat pada tabel dibawah ini:

Tabel 4. Nilai Siswa Kondisi Awal dan Siklus 1

\begin{tabular}{|c|c|c|c|c|}
\hline No & Kategori Nilai & $\begin{array}{c}\text { Kondisi } \\
\text { awal }\end{array}$ & Siklus 1 & Siklus 2 \\
\hline
\end{tabular}




\begin{tabular}{|c|c|c|c|c|}
\hline 1 & $\begin{array}{c}\text { Belum Tuntas } \\
(<\mathrm{KKM})\end{array}$ & $79,3 \%$ & $37,9 \%$ & \\
\hline 2 & Tuntas $(=/>\mathrm{KKM})$ & $20,7 \%$ & $62,1 \%$ & \\
\hline
\end{tabular}

Kalau kita lihat dari tabel di atas menunjukkan bahwa hasil belajar siswa mengalami peningkatan setelah dilakukan tindakan. Persentase siswa yang belum tuntas mengalami penurunan dari kondisis awal ke siklus 1 (79,3\% menjadi $37,9 \%$ ). Sedangkan persentase siswa yang sudah tuntas mengalami kenaikan dari kondisi awal ke siklus 1 ( 20,7\% menjadi 62,1\%).

Indikator keberhasilan dari PTK ini adalah PTK dikatakan berhasil jika persentase siswa yang nilai hasil belajarnya sudah tuntas mencapai $80 \%$. Dari tabel menunjukkan bahwa persentase siswa yang nilainya tuntas baru mencapai 62,1\%, maka PTK harus dilanjutkan pada siklus 2.

2) Refleksi Siklus 1

Setelah mengkaji proses pembelajaran yang dilakukan pada siklus 1, bagaimana keaktifan siswa dan bagaimana hasil belajar siswa, peneliti melakukan refleksi. Kegiatan ini dibantu oleh teman sejawat. Tujuannya adalah untuk mendapatkan solusi perbaikan yang dapat dilakukan pada siklus 2 . Adapun hasil dari kegiatan refleksi itu adalah sebagai berikut:

a) Guru (peneliti) harus bisa mengelola waktu agar ada cukup waktu yang diberikan kepada peserta didik untuk membahas penampilan temannya.

b) Guru (peneliti) harus lebih bisa memotivasi peserta didik siswa dalam setiap kegiatan, yakni dengan cara memperhatikan satu persatu setiap siswa apakah dia sudah ikut terlibat dalam pembelajaran atau belum.

c) Guru (peneliti) harus selalu mendiskusikan hasil kerja kelompok, sehingga setiap kelompok mengetahui bagian mana yang harus diperbaiki dan bagian mana yang sudah benar.

2. Siklus 2

a. Perencanaan tindakan siklus 2

Rencana tindakan pada siklus 2 bertujuan untuk memperbaiki keaktifan dan hasil belajar siswa. Yang pertama di buat Rencana Pelaksanaan Pembelajaran (RPP) untuk dua kali pertemuan (RPP terlampir). RPP dikembangkan dengan menggunakan model pembelajaran cooperative learning metode role playing sesuai dengan langkah-langkah yang dibahas dalam kajian teori. Kompetensi yang akan diajarkan dalam RPP ini adalah KD 3.2. RPP ini akan diimplementasikan pada pertemuan pertama dan kedua, yakni tanggal 7 Oktober 2020 dan 15 Oktober 2020.

Secara umum langkah-langkah pembelajaran pada siklus 2 sama dengan siklus 1. Perbedaannya adalah pada tindakan pada setiap langkah dioptimalkan sesuai hasil refleksi pada siklus 1. Yang diperbaiki adalah sebagai berikut :

1) Guru (peneliti) harus bisa mengelola waktu agar waktu yang diberikan kepada peserta didik untuk membahas penampilan temannya cukup.

2) Guru (peneliti) harus lebih bisa memotivasi peserta didik siswa dalam setiap kegiatan, yakni dengan cara memperhatikan satu persatu setiap siswa apakah dia sudah ikut terlibat dalam pembelajaran atau belum.

3) Guru (peneliti) harus selalu mendiskusikan hasil kerja kelompok, sehingga setiap kelompok mengetahui bagian mana yang harus diperbaiki dan bagian mana yang sudah benar.

b. Pelaksanaan Tindakan Siklus 2

Berdasarkan hasil observasi yang dilakukan oleh dua observer (teman sejawat), dengan menggunakan lembar observasi (terlampir) dalam dua kali pertemuan, yakni pertemuan pertama hari Rabu tanggal 7 Oktober 2020 dan pertemuan ke dua 
hari Kamis tanggal 15 Oktober 2020, ditemukan bahwa proses pembelajaran berlangsung sebagai berikut:

1) Pertemuan pertama

Proses pembelajaran secara umum sudah baik dan sesuai dengan langkahlangkah metode role playing. Menurut observer 1, Pembelajaran sudah berlangsung bagus, siswa aktif dan terlibat dalam kegiatan. Demikian juga menurut observer 2 tidak jauh berbeda.

2) Pertemuan ke dua

Proses pembelajaran secara umum sudah baik dan sesuai dengan rencana tindakan pada RPP pertemuan 1. Kedua observer menyatakan bahwa pembelajaran sudah berlangsung dengan sangat bagus.

c. Hasil Penelitian dan Refleksi Siklus 2

1) Hasil Penelitian Siklus 2

a) Hasil Keaktifan

Menurut observer 1 didapatkan data bahwa, persentase siswa yang memiliki keaktifan rendah ada $6,9 \%$, sedang 55,2\%, dan tinggi 37,9\%. Menurut observer 2 didapatkan data bahwa, persentase siswa yang memiliki keaktifan rendah ada $10,3 \%$, sedang $51,7 \%$, dan tinggi $38,0 \%$.

Jika di rata-rata dari dua observer tersebut diperoleh data bahwa persentase siswa yang keaktifannya rendah ada 8,6\%, sedang 53,4\% dan tinggi 38,0\%. Kalau dibandingkan dengan kondisi awal adalah sebagai berikut:

Tabel 5. Keaktifan Siswa Kondisi Awal, Siklus 1 dan Siklus 2

\begin{tabular}{|c|l|c|c|c|}
\hline No & \multicolumn{1}{|c|}{$\begin{array}{c}\text { Kategori } \\
\text { Keaktifan }\end{array}$} & Kondisi awal & Siklus 1 & Siklus 2 \\
\hline 1 & Tinggi & $3,4 \%$ & $6,9 \%$ & $38,0 \%$ \\
\hline 2 & Sedang & $34,4 \%$ & $43,1 \%$ & $53,4 \%$ \\
\hline 3 & Rendah & $62,0 \%$ & $50,0 \%$ & $8,6 \%$ \\
\hline
\end{tabular}

Tabel di atas menunjukkan bahwa keaktifan siswa dari kondisi awal, siklus 1 dan siklus 2 mengalami peningkatan. Dengan demikian PTK ini sudah dikatakan berhasil karena siswa yang keaktifannya dengan kategori rendah berada di bawah $10 \%$.

b) Hasil Belajar

Berdasarkan hasil tes yang dilakukan di akhir siklus 2 diketahui bahwa ratarata nilai yang diperoleh peserta dididk untuk mapel bahasa Inggris KD 3.2 (KKM 76) adalah 76,7 . Dengan kategori belum tuntas dan tidak tuntas sebagai berikut :

- Persentase belum tuntas : $5 / 29 \times 100 \%=17,2 \%$

- Persentase sudah tuntas : $24 / 29 \times 100 \%=82,8 \%$

Bila dibandingkan dengan hasil belajar pada kondisi awal, hasil belajar pada siklus ini mengalami peningkatan. Hal ini dapat dilihat pada tabel dibawah ini:

Tabel 6. Nilai Siswa Kondisi Awal, Siklus 1 ,dan Siklus 2

\begin{tabular}{|c|c|c|c|c|}
\hline No & Kategori Nilai & $\begin{array}{c}\text { Kondisi } \\
\text { awal }\end{array}$ & Siklus 1 & Siklus 2 \\
\hline 1 & $\begin{array}{c}\text { Belum Tuntas } \\
(<\mathrm{KKM})\end{array}$ & $79,3 \%$ & $37,9 \%$ & $17,2 \%$ \\
\hline 2 & Tuntas (=/>KKM) & $20,7 \%$ & $62,1 \%$ & $82,8 \%$ \\
\hline
\end{tabular}


Kalau kita lihat dari tabel di atas menunjukkan bahwa hasil belajar siswa mengalami peningkatan setelah dilakukan tindakan. Persentase siswa yang belum tuntas mengalami penurunan dari kondisis siklus 1 ke siklus 2 (dari $37,9 \%$ menjadi $17,2 \%$ ). Sedangkan persentase siswa yang sudah tuntas mengalami kenaikan siklus 1 ke siklus 2 ( dari 62,1\% menjadi 82,8\%).

Indikator keberhasilan dari PTK ini adalah, PTK dikatakan berhasil jika persentase siswa yang nilai hasil belajarnya sudah tuntas mencapai $80 \%$. Dengan demikian PTK sudah dikatakan berhasil karena nilai tuntas telah mencapai $82,8 \%$ (tidak dilanjutkan pada siklus 3).

2) Refleksi Siklus 2

Setelah mengkaji proses pembelajaran yang dilakukan pada siklus 2, bagaimana keaktifan siswa dan bagaimana hasil belajar siswa, peneliti melakukan refleksi. Kegiatan ini dibantu oleh teman sejawat.

Dari analisis data keaktifan siswa menunjukkan kondisi awal, siklus 1 dan siklus 2 mengalami peningkatan yang cukup berarti. Pada siklus 2 persentase siswa yang keaktifannya rendah sudah mencapai $8,6 \%$. Jadi sudah mencapai target yang ditetapkan oleh PTK ini yaitu di bawah $10 \%$.

Dari analisi data hasil belajar siswa menunjukkan dari kondisi awal, siklus 1 dan siklus 2 juga mengalami peningkatan. Persentase hasil belajar pada siklus 2 sudah melebihi target yaitu lebih dari $80 \%$.

Jadi secara umum dikatakan bahwa proses pembelajaran pada siklus 2 sudah berlangsung sangat bagus. Tindakan yang dilakukan oleh guru juga mengalami peningkatan dan perbaikan. Maka siklus PTK ini selesai pada siklus 2 saja.

\section{Pembahasan}

Keaktifan dan hasil belajar siswa sangat ditentukan oleh proses pembelajaran. Proses pembelajaran yang monoton, kurang menarik, tentu akan berdampak bagi keaktifan dan hasil belajar siswa. Guru perlu menerapkan model pembelajaran yang tepat untuk proses pembelajarannya. Metode role playing merupakan salah satu model pembelajaran cooperative learning yang bisa digunakan untuk meningkatkan keaktifan dan hasil belajar siswa.

Beberapa penelitian yang terdahulu yang relevan dengan penelitian yang penulis lakukan adalah sebagai berikut:

Penelitian yang berjudul "Penerapan Metode Role Playing untuk Meningkatkan Hasil Belajar Siswa Pada Materi Perkembangbiakan Makhluk Hidup" yang ditulis oleh Ni Made Mega Hariyani pada tahun 2019 menyatakan bahwa hasil penelitian menunjukkan peningkatan hasil belajar siswa dimana dilihat dari aktivitas siswa meningkat dari siklus I $60,56 \%$ ke siklus II 87,92\%, dan peningkatan hasil belajar dapat dilihat dari ketuntasan belajar siswa jika dilihat dari data awal 36,67\% meningkat ke siklus I 73,33\% dan meningkat lagi ke silkus II 86,67\% yaitu sudah sesuai dengan target yang diharapkan. Terbukti metode role playinging dapat meningkatkan hasil belajar siswa mata pelajaran IPA, karena metode role playinging melibatkan siswa dalam proses pembelajaran secara aktif dalam situasi yang menyenangkan, sehingga siswa tidak hanya aktif secara fisik, tetapi juga aktif secara mental dan suasana kelas semakin hidup.

Selanjutnya adalah penelitian yang dilakukan oleh Jehaut dan kawan-kawan yang berjudul "Upaya Meningkatkan Motivasi Belajar PPKn pada Materi Sumpah Pemuda Melalui Metode Role Playing". Hasil yang diperoleh pada setiap siklus dalam pembelajaran melalui metode role playing adalah siklus I aktivitas belajar peserta didik memiliki jumlah skor 66 dan 88 dengan presentase $37 \%$ dan 49\%, pada siklus II memiliki jumlah skor 115 dan 134 dengan prsentase 62\% dan 74\%, dan pada siklus III memiliki jumlah skor 153 dan 162 dengan prsentase 85\% dan 90\%, ini dapat dikatakan bahwa motivasi belajar peserta didik meningkat dengan menggunakan metode role playing. 
Peneliti ini menyimpulkan bahwa belajar dengan menggunakan metode role playing dapat meningkatkan motivasi belajar PPKn pada materi sumpah pemuda.

Tahap-tahap belajar role playing menunjukkan proses pembelajaran yang bervariasi dan secara umum dapat memberikan dampak terhadap keaktifan dan hasil belajar siswa. Guru harus punya kemampuan yang lebih dalam menerapkan metode role playing ini. Pembahasan mengenai penerapan model belajar ini bisa diuraikan sebagai berikut:

1. Siklus 1 :

Pada siklus ini guru telah menerapkan langkah-langkah metode role playing sesuai dengan prosedur. Namun pelaksanaannya kurang optimal karena ada beberpa langkah yang harus lebih ditingkatkan, yakni (a) kesempatan yang diberikan kepada peserta didik untuk membahas penampilan temannya masih kurang, (b) Guru harus memastikan setiap siswa untuk aktif dalam kegiatan, (c) Guru kurang optimal dalam membahas hasil kerja kelompok. Namun secara umum siklus ini hasilnya lebih baik dari kondisi awal dari aspek keaktifan siswa dan hasil belajar siswa.

Setelah dilakukan diskusi refleksi, kekurangan-kekurangan tersebut diperbaiki, yakni dengan (1) Guru (peneliti) harus bisa mengelola waktu agar kesempatan kepada peserta didik untuk membahas penampilan temannya cukup waktu, (2) Guru (peneliti) harus lebih aktif lagi dalam memastikan setiap siswa untuk aktif dalam kegiatan, yakni dengan cara memperhatikan satu persatu setiap siswa apakah dia sudah ikut terlibat dalam pembelajaran atau belum, (3) Guru (peneliti) harus selalu mendiskusikan hasil kerja kelompok, sehingga setiap kelompok mengetahui bagian mana yang harus diperbaiki dan bagian mana yang sudah benar.

2. Siklus 2:

Dari analisis data hasil belajar siswa menunjukkan dari kondisi awal, ke siklus 1 dan siklus 2 mengalami peningkatan yang cukup berarti. Persentase hasil belajar pada siklus 2 sudah mencapai target, bahkan melebihi. Data ini menunjukkan bahwa proses pembelajaran yang dilakukan oleh guru (peneliti) memberikan dampak bagi peningkatan hasil belajar siswa. Untuk lebih jelasnya dapat dilihat pada tabel dan grafik berikut ini:

Tabel 7. Hasil Belajar Siswa pada Kondisi Awal, Siklus 1, dan Siklus 2

\begin{tabular}{|c|c|c|c|c|}
\hline No & Kategori Nilai & Kondisi awal & Siklus 1 & Siklus 2 \\
\hline 1 & Belum Tuntas $(<\mathrm{KKM})$ & $79,3 \%$ & $37,9 \%$ & $17,2 \%$ \\
\hline 2 & Tuntas (=/>KKM) & $20,7 \%$ & $62,1 \%$ & $82,8 \%$ \\
\hline
\end{tabular}

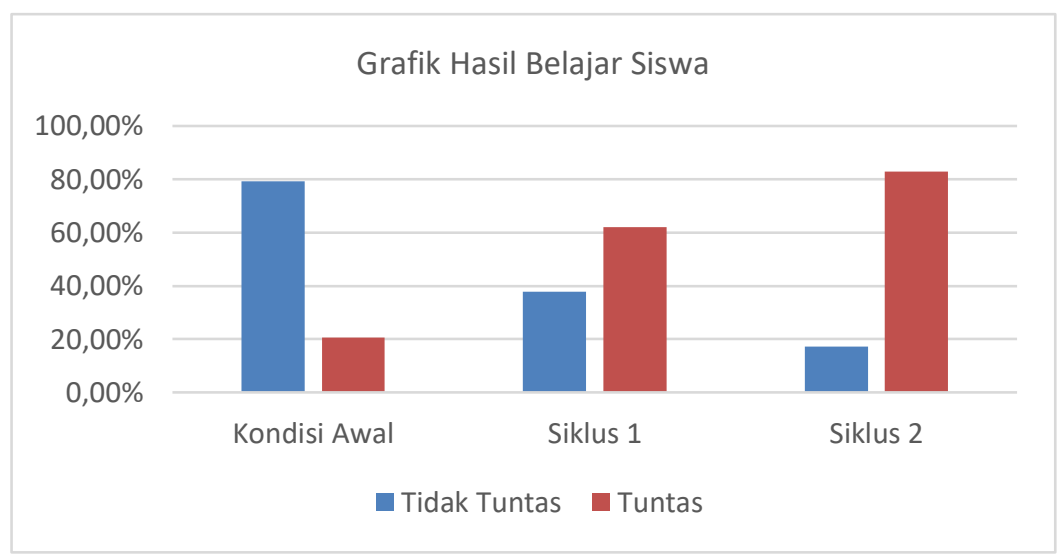

Grafik 1. Hasil Belajar Siswa pada Kondisi Awal, Siklus 1, dan Siklus 2

Sedangkan dari analisis data keaktifan siswa menunjukkan kondisi awal, siklus 1 dan siklus 2 mengalami peningkatan. Pada siklus 2 persentase siswa yang keaktifannya 
rendah sudah menurun menjadi $8,6 \%$. Jadi sudah mencapai target seperti yang ditetapkan indikator kinerja PTK ini. Untuk lebih jelasnya dapat dilihat pada tabel dan grafik berikut ini.

Tabel 8. Keaktifan Siswa pada Kondisi Awal, Siklus 1 dan Siklus 2

\begin{tabular}{|c|l|c|c|c|}
\hline No & $\begin{array}{c}\text { Kategori } \\
\text { Keaktifan }\end{array}$ & Kondisi awal & Siklus 1 & Siklus 2 \\
\hline 1 & Tinggi & $3,4 \%$ & $6,9 \%$ & $38,0 \%$ \\
\hline 2 & Sedang & $34,5 \%$ & $43,1 \%$ & $53,4 \%$ \\
\hline 3 & Rendah & $62,1 \%$ & $50,0 \%$ & $8,6 \%$ \\
\hline
\end{tabular}

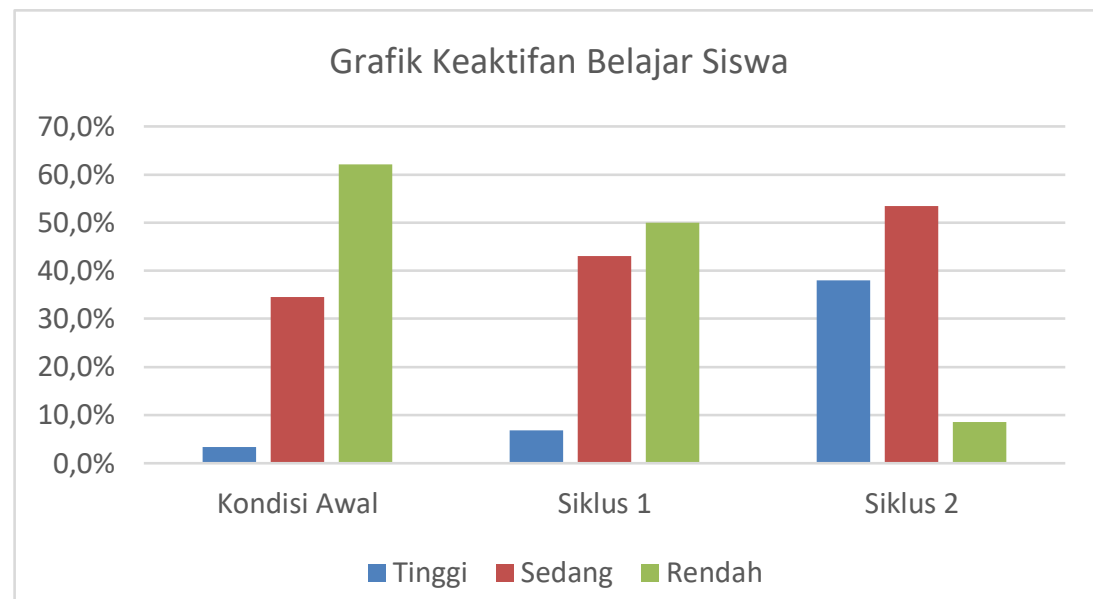

Grafik 2. Keaktifan Belajar Siswa pada Kondisi Awal, Siklus 1, dan Siklus 2

Dari analisi data menunjukkan pembelajaran yang dilakukan pada siklus 2 jauh lebih baik dibanding pada siklus 1 . Secara umum proses pembelajaran pada siklus 2 kategorinya sangat bagus. Dari data-data tersebut menunjukkan bahwa tindakan yang dilakukan oleh guru (peneliti) terus mengalami perbaikan dan sudah mencapai sesuai yang ditetapkan. Maka siklus PTK ini selesai pada siklus 2 saja.

\section{KESIMPULAN}

Sesuai hasil penelitian dan pembahasan, maka dapat dikemukakan bahwa setelah dilakukan tindakan dengan menggunakan penerapan metode role playing pada peserta didik kelas XII Madrasah Aliyah Negeri 5 Sleman terjadi perubahan keaktifan dan hasil belajar peserta didik. Perubahan ini nampak pada hasil observasi maupun test yang didapat dari pra tindakan, tindakan pada siklus 1, dan tindakan dari siklus 2. Data perkembangan hasil peningkatan hasil belajar peserta didik dapat dilihat dari perolehan nilai tuntas peserta didik pada masing-masing siklus mengalami peningkatan yakni nilai hasil belajar tuntas $62,1 \%$ pada siklus 1 menjadi $82,8 \%$ pada siklus 2 . Sedang persentase nilai hasil belajar siswa tidak tuntas mengalami penurunan. Dengan hasil penelitian ini, penulis menyarankan kiranya rekan-rekan guru yang lain dapat mencoba menerapkan metode role playing pada materi yang sesuai.

\section{DAFTAR PUSTAKA}

Agus, M. (2016). Sintaks 45 metode pembelajaran dalam student centered learning (SCL). Malang: Universitas Muhammadiyah Malang Press.

Amri, S. (2013). Pengembangan dan Model Pembelajaran dalam Kurikulum 13. Jakarta: Prestasi Pustakaraya.

Arikunto, S. (2009). Penelitian Tindakan Kelas. Jakarta: Bumi Aksara.

Dimyati. (2009). Belajar dan Pembelajaran. Jakarta: Rineka Cipta.

Hamalik, O. (2001). Proses Belajar Mengajar. Jakarta: PT Bumi Aksara 
Sudjana, N. (2004). Dasar-dasar Proses Belajar Mengajar. Bandung: PT. Remaja Rosdakarya. Susanto, A. (2016). Teori Belajar dan Pembelajaran di Sekolah Dasar. Jakarta: Prenadamedia Group.

Sardiman. (1988). Interaksi dan Motivasi Belajar Mengajar. Jakarta: Rajawali Press.

Thobroni, M., dan Mustofa, A. (2012). Belajar dan Pembelajaran. Yogyakarta:Ar-Ruzz Media.

Zaini, H., dkk. (2008). Strategi Pembelajaran Aktif. Yogyakarta: Pustaka Insan Madani.

Hariyani, N. (2019). Penerapan Metode Role playinging Untuk meningkatkan Hasil Belajar Siswa pada Materi Perkembangbiakan Makhluk Hidup. Widya Genitri: Jurnal Ilmiah Pendidikan, Agama dan Kebudayaan Hindu. 19-21.

Jehaut, Y., Harini, H., Ayuningrum, S. (2020). Upaya Meningkatkan Motivasi Belajar pada Materi Sumpah Pemuda melalui Metode Role playinging. Jurnal STKIP Kusumanegara. 